\title{
Erratum to: Development and Testing of 2D Finite Difference Model in Open Channels
}

\author{
Truong An Dang ${ }^{1} \cdot$ Sang Deog Park ${ }^{2}$
}

Published online: 2 August 2016

(C) Springer International Publishing Switzerland 2016

\section{Erratum to: Environ Model Assess}

\section{DOI 10.1007/s10666-016-9520-8}

Due to an oversight, the given and family names for both authors were interchanged in the original publication. The correct names should be: Truong An Dang and Sang Deog Park.

Truong An Dang

dangtruongan@tdt.edu.vn

Sang Deog Park

sdpark@gwnu.ac.kr

1 Sustainable Management of Natural Resources and Environment Research Group, Faculty of Environment and Labour Safety, Ton Duc Thang University, 19 Nguyen Huu Tho Str., Dist 7, Ho Chi Minh City, Vietnam

2 Department of Civil Engineering, Gangneung-Wonju National University, Gangneung, Gangwon-Do 210-702, South Korea 